\title{
THE CONCEPT OF MODELING A PSYCHOLOGICALLY COMFORTABLE ENVIRONMENT IN PHYSICAL EDUCATION ORGANIZATIONS
}

\author{
I.S. Osipova, i.s.osipova@mail.ru, \\ S.L. Suvorova, alex97@shadrinsk.net, \\ T.V.Khilchenko, tkhill@rambler.ru \\ Shadrinsk State Pedagogical University, Shadrinsk, Russian Federation
}

\begin{abstract}
Current trends in the sphere of physical education and sports are reflected in the functioning of physical education organizations. One of the conditions for success is the creation and management of a psychologically comfortable environment. This article is an attempt to solve the problem of modeling a psychologically comfortable environment in physical education organizations in administrative, methodological and technological aspects.

To consider the theoretical aspects of the problem and develop the concept, the methods of the literature review, analysis of sports organizations teachers' professional activities, observation and modeling were used. The result of scientific research was the authors' concept of modeling a psychologically comfortable environment in physical education organizations. The conceptual components of a psychologically comfortable environment were identified. They are emotional, cognitive, and behavioral ones. The problem of creating a psychologically comfortable environment in a physical education organization is considered taking into account the principles of parity and participativeness, which allow us to analyze the effectiveness of modeling a psychologically comfortable environment in an organization.

Methodological and technological aspects of a practical solution to the problem are presented as the conditions for the implementation of the model developed by the authors. The conditions are: the formation of interpersonal relationships in a physical education organization based on the reference significance of the environment; psychological prevention and correction; the introduction of psychological strategies to support the employees of a physical education organization. These conditions and the concept were tested in a pilot version of the physical education organizations of Shadrinsk. The data obtained indicate the effectiveness of the concept and the conditions created.

Keywords: psychological environment, comfort, psychologically comfortable environment, management of a psychologically comfortable environment in sports organizations, the concept of modeling a psychologically comfortable environment in sports organizations.
\end{abstract}

\section{Introduction}

The purpose of the paper is to describe the variant of concept modeling of a psychologically comfortable environment in sports organizations.

Current trends in the field of education in the segment of training specialists in the sphere of physical education and sports, as well as in the system of activities of sports organizations, actualize the problems associated with ensuring stable and psychologically comfortable functioning of all processes within these systems. Such provision is logically associated with the concepts of "psychologically comfortable environment" and "creation and management of a psychologically comfortable environment".

These concepts, considered with extrapolation to the sphere of activity of physical education organizations, acquire the specifics of their meaningful content and the perspective of their interpretation. The article makes an attempt to present the authors' consideration of these concepts and description of the mechanisms for creating and managing a psychologically comfortable environment in sports organizations.

\section{Literature review}

It should be noted that the urgency of the problem of the formation of a psychologically comfortable environment in any organization is due to the high dynamics of the organization's development, which is the reason for the increased psychological stress of its employees, both individuals and the whole team, as the findings of L.N. Akimova [1], A.K. Kuznetsova [12], L.P. Matveeva [14] and others suggest. Increasing requirements for the level of professional qualification and competence of specialists, new 
social challenges, the need for professional flexibility and mobility are cited, according to foreign researchers Cesar Augusto Otero Vaghettik, Renato Sobral Monteiro-Junior, Mateus David Finco, Eliseo Reategui, Silvia Silva da Costa Botelho Exergames to the emergence of factors that adversely affect the overall psychological environment in the organization [19, p. 23-32].

The psychological environment in the study of M.V. Markeeva, A.E. Chuvashova is considered as a complex of external and internal conditions that affect the mental state of a person and his psychological comfort [13, p. 117-120]. The concept of the psychological environment is directly related to the concept of comfort, which is interpreted as living conditions, stay, environment, providing convenience, peace and comfort (in modern studies of E.N. Gogunova [7], T.V. Kornilova [11], S.L. Suvorova [24]).

It is necessary to distinguish between the external environment of direct exposure (immediate environment, or meso medium) and indirect exposure (macro environment), which is taken into account in our study.

\section{Methodology}

To determine the essence of a psychologically comfortable environment and develop a concept of modeling psychologically comfortable environment, we used the conceptual and terminological analysis method, which allowed us to establish the following. For the existence of a psychologically comfortable environment in the organization, the formation of appropriate conditions is necessary. Currently, there are many options for creating a psychologically comfortable environment, which depends not only on the leadership of the organization, but, above all, on external conditions, on the labor market itself [9, p. 99-102]. Of no small importance in the process of modeling the conditions of a psychologically comfortable environment is the managerial aspect, implemented by the head of the physical education organization. The priority task of the leader should be a goal that should be oriented towards creating a comfortable living environment, comprehensive development of the personality of employees, etc., and in which the mechanism of the decision impact on the sports organization personnel should be manifested in coordinated collective actions $[15,17]$.

Various conditions for the development of this environment, as well as systems for the formation of a psychologically comfortable environment, have led to the appearance of a variety of existing approaches to this problem $[3,6,10]$.
The first research task is that for effective activities in general and the activities of the organization in particular, the essence of a psychologically comfortable environment should be analyzed. Since psychological comfort is a state of inner satisfaction arising under the influence of any favorable conditions and circumstances [18], we interpret the psychologically comfortable environment as a stable psychological space within a certain corporate environment.

Psychologically comfortable environment is a platform for the high-quality implementation of planned activities and achieving the final result. A stable social and psychological state of the employee is the key to the success of his activities and increase professional competence, which positively affects the organization's activities in the framework of its activities $[2,21]$.

The specifics of the functioning of a sports organization involves taking into account its active activities in organizing, conducting, monitoring, improving sports areas. The internal environment of a sports organization, as a rule, includes financial, production (provision of fitness and health services), organizational, personnel, and marketing components. It is also important to take into account the external environment of the physical education organization, which can significantly affect its psychological environment.

It is customary to distinguish between the external environment of direct impact (immediate environment, or meso medium) and indirect impact (macro environment) [7, 11, 23-25].

The second research task is to analyze the external environment of direct impact, which includes studying the specifics of its impact on the organization. It should be born in mind that the organization itself can have a certain impact on the environment. The main processes of direct impact analysis can be attributed $[5,16]$ :

a) the analysis of the industry "Physical Culture and Sports" - the modern attractiveness of the industry is characterized, firstly, by the rapid increase in various sports and types of physical activity; secondly, an increasing number of people involved in physical exercises; thirdly, the construction of a variety of sports facilities that create comfortable conditions for classes; fourthly, the development of new wellness technologies and simulators; fifthly, the development of a regulatory framework that protects the rights of citizens of the country to be engaged in physical education and sports, etc.;

b) analysis of competition factors - the high attractiveness of the industry stimulates the opening 


\section{Непрерывное образование в течение жизни...}

of an increasing number of commercial physical culture and sports organizations offering a variety of sports and recreational services on the market; the existence of organizations producing a substitute product (other types of leisure activities of people), etc.;

c) analysis of consumers of fitness services the influence of the territorial location of the organization on its attendance by consumers is studied; socio-demographic (gender, age, educational level, etc.) and socio-psychological (habits, tastes, lifestyle, etc.) consumer characteristics; their attitude to physical education and sport; their satisfaction with health and fitness services, etc.;

d) analysis of suppliers of sports equipment and facilities - the cost of the supplied sports goods; ensuring and guaranteeing their quality; level of service for sporting goods, etc.

The analysis of factors of indirect impact on the physical education organization is associated with the study of the following set of factors: political, legal, economic, sociocultural and technological.

Depending on the influence of the above factors, strategic decisions are made on the development of physical education organization, which, in turn, affects the internal psychological environment of the organization [20, p. 5-7].

The third research task is to develop a schematic model of the concept for managing a psychologically comfortable environment in physical education organizations in order to increase the effectiveness of its activities. Note that the head of the physical education organization must take into account a number of factors affecting the formation of a comfortable psychological environment, in particular the following [8]:

1) the nature of professional relations in the team of the organization;

2) the content, organization and conditions of work;

3 ) features of the work of the governing bodies and self-government of the organization;

4) management style of the organization;

5) the degree of coincidence of the official and unofficial structure of the team;

6) socio-demographic and psychological characteristics of employees of the organization;

7) the size of the organization.

\section{Results}

The concept of modeling we developed for managing a psychologically comfortable environment in sports organizations can be effectively implemented only against the background of the relevant conditions, which we treat from the traditional point of view as the unity of all the necessary circumstances that create a certain environment.

The following conditions for the implementation of the model can be proposed.

1. The formation of interpersonal relations in the physical education organization, based on the reference significance of the environment. This condition assumes the existence and guarantee of emotional comfort, the ability to express one's point of view on the functioning and development of the physical education organization; respectful attitude to the personality of employees of the organization; maintaining personal dignity; the availability of the opportunity to seek help on the activities of the physical education organization, taking into account personal problems and difficulties; attention to requests and suggestions; help in choosing your own solution. An important position in creating this condition is the desire for satisfaction of the organization employees with the main characteristics of the process of professional and interpersonal interaction.

2. Providing psychological prevention and correction.

In cases of employee dissatisfaction with the state of the psychological environment in the organization (in one or all of its components: emotional, cognitive, behavioral), psychological prevention should be implemented, which involves promoting the full disclosure of the personality potential of the organization's employee, as well as the prevention of possible personal deformations in the process of professional and personal interactions. Psychological prevention contributes to the formation of an adequate and competent response to the manifestations of psychological discomfort among employees of a physical education organization. Correction is also important in this case, which may consist in eliminating the factors causing psychological discomfort, as well as in harmonizing the mental health of the organization's employees.

3. The introduction of psycho technology support staff athletic organization. A set of measures to ensure a psychologically comfortable environment in a physical education organization includes effective psycho technologies, which involve both creating the environment in the organization and its possible correction $[4 ; 22$, p. 221-225]. Such technologies include: conducting a system of psychological studies and trainings 


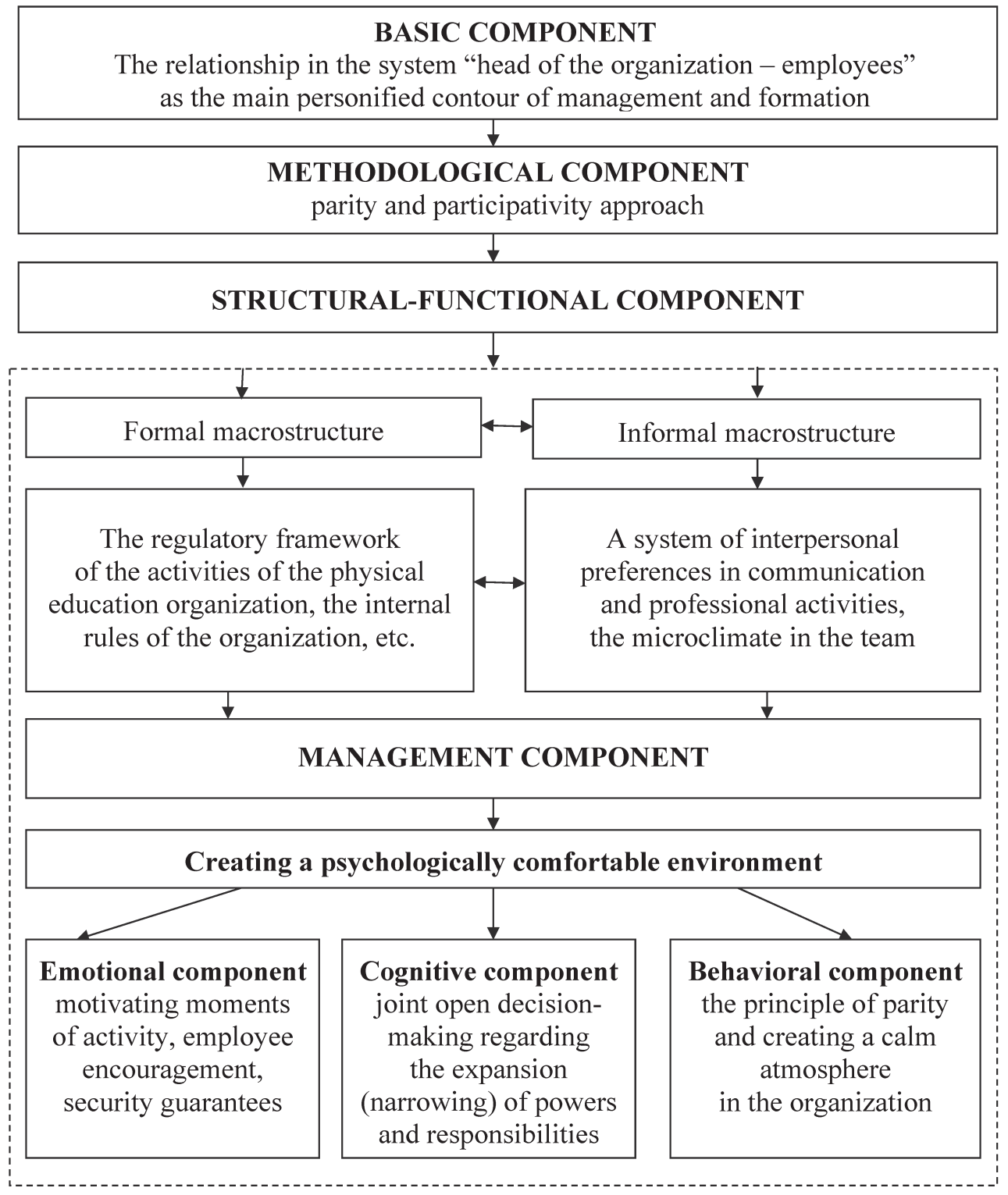

Fig. 1. The concept of modeling a psychologically comfortable environment in sports organizations

with all employees of the organization (after monitoring problems related to financial, production (providing fitness and fitness services), organizational, personnel, marketing components of professional activity); organization and conduct of group discussions and exercises on the issues of safe psychological interaction, comfortable communication, prospects for personal growth; conducting group discussions on the problems of the formation of psychological skills of partnership, dialogic communication, the implementation of techniques for creating safe psychological interaction and cooperation; conducting joint classes in the format of an imitation-roleplaying event, a business game, the result of which should be the development of models of psychologically comfortable interpersonal interaction in the organization.

The schematic model of the concept for managing a psychologically comfortable environment in sports organizations is as follows (Fig. 1).

\section{Conclusions}

The specifics of a modern physical education organization functioning depends on the requirements of society and the nomenclature of the most popular sports and recreational services. The main activity of a sports organization is implemented in several segments: financial, customer-oriented (providing fitness and fitness services), organizational, personnel, marketing. Such a variety of implemented activities and 


\section{Непрерывное образование в течение жизни...}

the presence of appropriate specialists inevitably leads to an disbalance in the mechanism for creating a psychologically comfortable environment in an organization.

The main process of regulation and maintenance of a psychologically comfortable environment in a physical education organization is management. In our study, for the effective management of a psychologically comfortable environment, the principles of parity and participatory principles have been proposed, which are implemented taking into account the main components of the collective professional activity: emotional, cognitive and behavioral. These provisions are reflected in the authors' model of managing a psychologically comfortable environment in physical education organizations, which can be implemented against the background of relevant conditions: the formation of interpersonal relationships in a physical education organization based on the reference significance of the environment; providing psychological prevention and correction; the introduction of psycho technologies to support employees of a sports organization.

The developed concept and the conditions for its implementation, in our opinion, will contribute to the resolution of possible conflicts between employees of the physical education organization, increase the level of tolerance and the willingness of employees to constructively resolve disputes and overcome stressful conditions.

\section{References}

1. Akimova L.N. Psihologiya Sporta [Sports Psychology]. Odessa, Studiya "Negotsiant" Publ., 2014. 127 p.

2. Antsupov A.Ya., Kovalev V.V. Socialnopsihologicheskaya ocenka personala [Social and Psychological Assessment of Staff]. Moscow, 2012. $391 \mathrm{p}$.

3. Galkin V.V. Ekonomika i upravlenie fizicheskoy kul'turoy i sportom [Economics and Management of Physical Culture and Sports]. Rostov n/D., Feniks Publ., 2006. 448 p.

4. Gibson D., Donneli D. Menedzhment v podrazdeleniyakh firmy [Management in the Departments of the Company]. Moscow, INFRA Publ., 2008. 204 p.

5. Gogunov E.N., Mart'yanov B.I. Psikhologiya fizicheskogo vospitaniya i sporta [Psychology of Physical Education and Sport]. Moscow, Izdatelskiy tsentr "Akademiya" Publ., 2014. 288 p.

6. Il'in E.P. Motivatsiya i motivy [Motivation and Motives]. St. Petersburg, Piter Publ., 2014. 509 p.
7. Jirásekivo I., Hurych E., Oborný J. Hermenuticals of Human Movement and Sport: Holism and Harmony. Physical Culture and Sport, Studies and Research, 2018, vol. 79, iss. 1, pp. 5-15. DOI: 10.2478/pcssr-2018-0015

8. Kibireva, O.N., Polynskaya, E.Yu. [Features of the Organization of a Comfortable Educational Environment in the Implementation of GEF of the third Generation]. Aktual'nye zadachi pedagogiki: materialy II Mezhdunar. nauch. konf. (g. Chita, iyun' 2012 g.) [Actual Problems of Pedagogy: Materials of the II Intern. Scientific Conf. (Chita, June 2012)]. Chita, Molodoy uchenyy Publ., 2012, pp. 99-102. (in Russ.)

9. Kolomeitsev, Yu.A. Vzaimootnosheniya $v$ sportivnoy komande [Relationship in a Sports Team]. Moscow, Fizkul'tura i sport Publ., 2012. $128 \mathrm{p}$.

10. Kornilova T.V. Psihologiya riska $i$ prinyatiya resheniy [Psychology of Risk and Decision Making]. Moscow, Aspekt Press Publ., 2013. $286 \mathrm{p}$.

11. Kuznecov, A.K. Fizicheskaya kul'tura [Physical Education]. St. Petersburg, Neva Publ., 2004. 324 p.

12. Markeeva M.V., Chuvashova A.E. [The Work of a Psychologist to Create a Psychologically Safe Educational Environment in a Secondary School]. Young Scientist, 2014, no 21 (1), pp. 117-120. (in Russ.)

13. Matveev, L.P. Teoriya i metodika fizicheskoy kul'tury [Theory and Methods of Physical Culture]. St. Petersburg, Lan' Publ., 2003. 248 p.

14. Pereverzin I.I. Menedzhment sportivnoy organizatsii [Sports Organization Management]. Moscow, Fizicheskaya kul'tura i sport Publ., 2006. 464 p.

15. Rozhkov P.A., Vinogradov P.A., Mochenov V.P. Normativnoe pravovoe i programmno-metodicheskoe obespechenie sfery fizicheskoy kul'tury $i$ sporta [Regulatory Legal and Methodological Support of the Sphere of Physical Culture and Sports]. Moscow, 2004. 157 p.

16. Smoleń A. Sports Real Estate Management. Physical Culture and Sport, Studies and Research, 2007, vol. 1 (XLV), pp. 210-227.

17. Smoleń A., Żyśko J. Technique TOWS/SWOT TechnikaTOWS/SWOT. Warsaw, 2005.

18. Suvorova S.L. Functional Map of a Profession: Problems of Modeling. Modern European Researches, 2016, no. 4, pp. 129-135.

19. Suvorova S.L., Blyasova I.Yu., Danilova V.V. Participative Management of Project and Research Activities in the educational "Col- 
lage" Environment. Revista ESPACIOS, 2018, vol. 39 , no. 29 , p. 13.

20. Suvorova S.L., Osipova I.Yu. Applied Competence Clusters (ACC) in Higher Education: Modeling of Outcomes-based Competence Profile. ICERI 2018 (11th annual International Conference on Education and New Learning Technologies). Palma de Mallorca (Spain), 12-14 November, 2018, pp. 8996-8999. DOI: 10.21125/iceri.2018.0659

21. Terminologiya sporta. Tolkovyy slovar' sportivnykh terminov [Sports Terminology. Explanatory Dictionary of Sports Terms]. Moscow, SportAkademPress Publ., 2001. 403 p.

22. Vaghetti C., Monteiro-Junior R., Finco M., Reategui E., Botelho S. Exergames Ex- perience in Physical Education. Physical Culture and Sport, Studies and Research, 2018, vol. 78, iss. 1, pp. 23-32. DOI: $10.2478 /$ pcssr-2018-0010

23. Voevodina N.A., Danilova L.P, Nurieva R.N. Sociologiya i psihologiya upravleniya [Sociology and Psychology of Management]. Moscow, Omega-L, Publ., 2010. 199 p.

24. Volkova I.P. Praktikum po sportivnoy psikhologii [Workshop on Sports Psychology]. St. Petersburg, Piter Publ., 2012. 288 p.

25. Zolotov M.I., Kuzin V.V., Kutepov M.E., Seyranov S.G. Menedzhment $i$ ehkonomika fizicheskoy kul'tury i sporta [Management and Economics of Physical Education and Sports]. Moscow, Izdatel'kiy tsentr "Akademiya" Publ., 2004. $432 \mathrm{p}$.

Received 5 December 2019

\title{
КОНЦЕПЦИЯ МОДЕЛИРОВАНИЯ ПСИХОЛОГИЧЕСКИ КОМФОРТНОЙ СРЕДЫ В СПОРТИВНЫХ ОРГАНИЗАЦИЯХ
}

\author{
И.С. Осипова, С.Л. Суворова, Т.В. Хильченко \\ Шадринский государственный педагогический университет, г. Шадринск, Россия
}

Современные тенденции в области образования и подготовки в сфере физической культуры и спорта отражаются на особенностях функционирования физкультурных организаций, одним из условий успешности которых является создание и управление психологически комфортной средой. Данная статья является попыткой решить проблему моделирования психологически комфортной среды в физкультурных организациях в управленческом и методико-технологическом аспектах.

Для рассмотрения теоретических аспектов проблемы и разработки концепции были использованы методы обзора научной литературы, анализа профессиональной деятельности педагогов физкультурных организаций, наблюдения и моделирования. Результатом научных изысканий стала авторская концепция моделирования психологически комфортной среды в физкультурных организациях, в которой выделены содержательные компоненты: эмоциональный, когнитивный, поведенческий. Проблема создания психологически комфортной среды в физкультурной организации рассматривается с учетом принципов паритетности и партисипативности, которые позволяют проанализировать эффективность моделирования психологически комфортной среды в организации.

Методико-технологические аспекты практического решения проблемы в статье представлены условиями реализации разработанной автором модели, к которым отнесены формирование межличностных отношений в физкультурной организации, базирующихся на референтной значимости среды; обеспечение психологической профилактики и коррекции; внедрение психотехнологий сопровождения сотрудников физкультурной организации. Данные условия и концепция были апробированы в пилотном варианте в физкультурных организациях г. Шадринска. Полученные данные свидетельствуют об эффективности концепции и создаваемых условий.

Ключевые слова: психологическая среда, комфорт, психологически комфортная среда, управление психологически комфортной средой в физкультурных организациях, концепиия моделирования психологически комфортной среды в физкультурных организациях. 


\title{
Непрерывное образование в течение жизни...
}

\author{
Лuтература \\ 1. Акимова, Л.Н. Психология спорта / Л.Н. Акимова. - Одесса: Студия «Негоџиант», 2014. - \\ $127 \mathrm{c}$. \\ 2. Аниупов, А.Я. Социально-психологическая оценка персонала / А.Я. Аниупов, В.В. Ковалев. - \\ М.: ЮНИТИ-ДАНА, 2012. - 391 c.
}

3. Галкин, В.В. Экономика и управление физической культурой и спортом: учеб. пособие для вузов / В.В. Галкин. - Ростов н/Д: Феникс, 2006. - 448 с.

4. Гибсон, Д. Менеджмент в подразделениях фирмы / Д. Гибсон, Д. Доннели. - М.: ИНФРА, 2008. $-204 c$.

5. Гогунов, Е.Н. Психология физического воспитания и спорта / Е.Н. Гогунов, Б.И. Мартьянов. - М.: Издат. иентр «Академия», 2014. - 288 с.

6. Ильин, Е.П. Мотиваџия и мотивы / Е.П. Ильин. - СПб.: Питер, 2014. - 509 с.

7. Jirásekivo, I. Hermenuticals of Human Movement and Sport: Holism and Harmony / I. Jirásekivo, E. Hurych, J. Oborný // Physical Culture and Sport, Studies and Research. - 2018. - Vol. 79. Iss. 1. - P. 5-15.

8. Кибирева, О.Н. Особенности организации комфортной образовательной среды в реализации ФГОС третьего поколения / О.Н. Кибирева, Е.Ю. Польнская // Актуальные задачи педагогики: материалы II Междунар. науч. конф. (г. Чита, июнь 2012 г.). - Чита: Молодой ученый, 2012. - C. 99-102.

9. Коломейцев, Ю.А. Взаимоотношения в спортивной команде / Ю.А. Коломейцев. - М.: Физкультура и спорт, 2012. - 128 с.

10. Корнилова, Т.В. Психология риска и принятия решений / Т.В. Корнилова. - М.: Аспект Пресс, 2013. $-286 \mathrm{c}$.

11. Кузнецов, А.К. Физическая культура / А.К. Кузнецов. - СПб.: Нева, 2004. - 324 с.

12. Маркеева, М.В. Работа психолога по созданию психологически безопасной образовательной среды в условиях общеобразовательной школь / М.В. Маркеева, А.Е. Чувашова // Молодой ученый. - 2014. - № 21 (1) - C. 117-120.

13. Матвеев, Л.П. Теория и методика физической культуры / Л.П. Матвеев. - СПб.: Лань, 2003. $-248 c$.

14. Переверзин, И.И. Менеджмент спортивной организации / И.И. Переверзин. - М.: Физ. культура и спорт, 2006. - 464 c.

15. Рожков, П.А. Нормативное правовое и программно-методическое обеспечение сферы физической культуры и спорта / П.А. Рожков, П.А. Виноградов, В.П. Моченов. - М., 2004. - 157 с.

16. Smoleń, A. Sports Real Estate Management / A. Smolen // Physical Culture and Sport, Studies and Research. - 2007. - Vol. 1 (XLV). - P. 210-227.

17. Smoleń, A. Technique TOWS/SWOT / A. Smoleń, J. Żyśko. - Warsaw, 2005.

18. Suvorova, S.L. Functional map of a profession: problems of modeling / S.L. Suvorova // Modern European Researches. - 2016. - No. 4. - P. 129-135.

19. Suvorova, S.L. Participative Management of Project and Research Activities in the Educational "Collage" Environment / S.L. Suvorova, I.Yu. Blyasova, V.V. Danilova // Revista ESPACIOS. - 2018. Vol. 39, No. 29. - P. 13.

20. Suvorova, S.L. Applied competence clusters (ACC) in higher education: modeling of outcomesbased competence profile / S.L. Suvorova, I.Yu. Osipova // ICERI 2018 (11th annual International Conference on Education and New Learning Technologies). Palma de Mallorca (Spain), 12-14 November, 2018. - P. 8996-8999.

21. Терминология спорта. Толковый словарь спортивных терминов. - М.: СпортАкадемПресс, 2001. -403 c.

22. Exergames Experience in Physical Education / C. Vaghetti, R. Monteiro-Junior, M. Finco et al. // Physical Culture and Sport, Studies and Research. - 2018. - Vol. 78. - Iss. 1. - P. 23-32.

23. Воеводина, Н.А. Социология и психология управления / Н.А. Воеводина, И.А. Данилова, Р.Н. Нуриева. - М.: Омега-Л, 2010. - 199 с.

24. Волкова, И.П. Практикум по спортивной психологии / И.П. Волков. - Питер, 2012. - 288 c.

25. Менеджмент и экономика физической культуры и спорта / М.И. Золотов, В.В. Кузин, М.Е. Кутепов, С.Г. Сейранов. - М.: Издат. иентр «Академия», 2004. - 432 с. 
Осипова Ирина Сергеевна, кандидат педагогических наук, доцент, декан факультета физической культуры, Шадринский государственный педагогический университет, г. Шадринск, i.s.osipova@mail.ru.

Суворова Светлана Леонидовна, доктор педагогических наук, профессор, профессор кафедры теории и практики германских языков, Шадринский государственный педагогический университет, г. Шадринск, alex97@shadrinsk.net.

Хильченко Татьяна Викторовна, кандидат педагогических наук, доцент, доцент кафедры теории и практики германских языков, Шадринский государственный педагогический университет, г. Шадринск, tkhill@rambler.ru.

Поступила в редакцию 5 декабря 2019 г.

\section{ОБРАЗЕЦ ЦИТИРОВАНИЯ}

Osipova, I.S. The Concept of Modeling a Psychologically Comfortable Environment in Physical Education Organizations / I.S. Osipova, S.L. Suvorova, T.V. Khilchenko // Вестник ЮУрГУ. Серия «Образование. Педагогические науки». - 2020. - Т. 12, № 1. - С. 44-51. DOI: $10.14529 /$ ped200104

\section{FOR CITATION}

Osipova I.S., Suvorova S.L., Khilchenko T.V. The Concept of Modeling a Psychologically Comfortable Environment in Physical Education Organizations. Bulletin of the South Ural State University. Ser. Education. Educational Sciences. 2020, vol. 12, no. 1, pp. 44-51. DOI: $10.14529 /$ ped200104 